\title{
Tim O'Brien's “Bad” Vietnam War: The Things They Carried \& Its Historical Perspective
}

\author{
Ramtin Noor-Tehrani (Noor) Mahini \\ Acalanes High School, Lafayette, California, USA \\ Erin Barth \\ Acalanes High School, Lafayette, California, USA \\ Jed Morrow \\ Acalanes High School, Lafayette, California, USA
}

\begin{abstract}
Tim O'Brien was sent to Vietnam as a foot soldier in 1969, during the later part of the Vietnam War that can be called the "bad" or unwinnable war. Based on his experience, O'Brien's writing about the Vietnam War in his award-winning fiction novels is always "bad," meaning that the war was terrible for American grunts like himself, his fellow soldiers, and Vietnamese civilians, with practically no good or inspiring stories. Nevertheless, $O$ 'Brien touches upon almost all problems of American soldiers in the Vietnam War, but not many peer-reviewed authors or online literary analysis websites could identify or discuss them all. The purpose of this article is to discuss the war details in O'Brien's The Things They Carried and its historical perspective, so that young middle and high school readers can understand the meaning behind Tim O'Brien's writing about the Vietnam War. The goal is to summarize the entire big picture of the Vietnam War and to help students determine whether American soldiers' actions, as described by Tim O'Brien, were morally right or wrong and were legal or forbidden according to the US law of war. The war-related issues that $O$ 'Brien mentioned in this novel are: boredom and meaningless death, abusive violence ${ }^{1}$ toward $^{2}$ Vietnamese noncombatants, drug use, in-fighting, thefts within barracks, grief, rage, self-mutilation, mutilation of enemy corpses, and senseless animal and civilian killings.
\end{abstract}

Index Terms-Tim O'Brien, The Things They Carried, Vietnam War, American Casualties, abusive violence, military drug use, mutilation of corpses, mutilation of animals, civilian collaboration, village bombing

\section{INTRODUCTION}

By the end of the Vietnam War - the time the last American was airlifted from the top of the American Embassy in Saigon on April 30, 1975 - a total of 738 billion dollars were burned, more than 58,000 American lives perished (Kent, 2015), 300,000 able American bodies were maimed and disabled, and another 500,000 veterans were plagued by the effects of post traumatic stress disorder (PTSD). That is all left - hard and cold statistics - for a painful Vietnam War experience in Americans' mind and conscience. Yet some of the unexpected side aspects of wars are heart-wrenching stories from the pen of talented writers like Tim O'Brien to keep human experience alive through decades. As one of American prominent writers, Tim O'Brien skillfully mixes his real wartime experience with fiction in his awardwinning novels. Recently, two days before the ten-part, 18-hour documentary "The Vietnam War" by Ken Burns and Lynn Novick was aired on Public Broadcasting Service (PBS), the New York Times readers voted The Things They Carried (O'Brien, 1990) to be one of the ten best books about the Vietnam War (Ellingwood, 2017), among roughly 30,000 publications on the subject. The Vietnam War depicted in all O'Brien's fiction novels is almost always representative of the "bad" part of the Vietnam War. Although O'Brien wants to create a "sense of passion" and to discuss themes "of courage, rectitude, enlightenment, holiness, trying to do the right thing in the world" (Coffey, 1990), or to focus on the "language about the war and about the human heart" (Gross, 2010), his writing unwittingly gives us a long list of reasons why the mighty, supreme United States (US) of America lost the war in Vietnam, one of the poorest third world countries on earth. Previous peer-reviewed publications on Tim O'Brien's novels and online literary analysis websites (such as litcharts.com, cliffsnotes.com, or sparknotes.com) mostly focus on literary devices and a few narrow war aspects of his books. Even the most comprehensive review on Tim O'Brien's work by Heberle does not point out these war-related issues within their historical context (Heberle, 2001). Because this article addresses the historical perspective of war-related issues presented by O'Brien in The Things They Carried, its purpose is to help young middle and high school readers understand the entire big war picture and the meaning behind Tim O'Brien's writing about the Vietnam War, in order to recognize which American soldiers' actions - as described by O'Brien - may not be morally or legally correct under the US law of war.

\footnotetext{
1 "Abusive Violence" is a term used by Laufer et al. (1984) in "War Stress and Trauma: The Vietnam Veteran Experience"
} 


\section{AUTHOR}

William Timothy O'Brien Jr. (Tim O’Brien) was born on October 1, 1946 in Austin, Minnesota (MN) but grew up with two younger siblings in Worthington, MN, a small rural town of about nine thousand residents. O'Brien was the oldest of the three children of William T. O'Brien, an insurance salesman, and Ava E. O'Brien, a teacher. Both of his parents served in the Navy during World War II. Being a "chubby, friendless, and lonely" child terrible at playing baseball (O'Brien, 1994), he escaped boredom and reality by spending a great deal of time in the Noble's County Library. Despite the respect the O'Brien had toward his father, their relationship was troubled due to his father's alcoholism. O'Brien also professed to be a dreamer and a self-taught magician (Buchholz, 2012).

O'Brien received a Bachelor's Degree in Political Science from Macalester College in 1968 and was drafted in the same year. Fiercely opposing the Vietnam War, he was a campaign supporter/volunteer for Eugene McCarthy, a peace candidate in the 1968 presidential election and a congressman from Minnesota. O'Brien considered going AWOL (Absent Without Official Leave) and running to Canada during his training, but ultimately decided to stay. He served in the $3^{\text {rd }}$ Platoon, Company A, $5^{\text {th }}$ Battalion, $46^{\text {th }}$ Infantry Regiment, $23^{\text {rd }}$ Infantry Division in Vietnam. His Battalion contained the Charlie Company that committed the August 16, 1968 Mỹ Lai Massacre (Mỹ means "Pretty or American" and Lai means "Mixed Race"), roughly one year before his arrival. During his 14-month military service in Vietnam (1969-1970), he rose to the rank of sergeant and received the Purple Heart medal from being wounded twice.

After his military service, O'Brien did his graduate studies in government and political science at Harvard University. In 1973, he began his career as an intern and national affairs reporter for the Washington Post and married Anne Weller (the couple divorced in 1995). Shifting his career to fiction writing, O'Brien debuted with If I Die In A Combat Zone, Box Me Up and Ship Me Home, named Outstanding Book (of 1973) by The New York Times. In his writing piece entitled "The Vietnam in Me" published in The New York Times on October 2, 1994, O'Brien described his return trip to visit Mỹ Lai and Quảng Ngãi (meaning “Extensive Righteousness") in February of that year with his companion/love interest Kate Phillips. He describes in details his warm interaction with Mỹ Lai survivors, interspersed with his feelings about the breakup with Kate in the June/July time frame. At this time, O'Brien had to take medication to combat his depression and the double trauma that made him contemplate suicide. He later married Meredith Baker and currently lives in Austin, Texas with his wife and two sons, Timmy and Tad (Buchholz, 2012).

O’Brien has won several literary awards: 1976/1978 O. Henry Award, 1977 Best American Short Stories Award, 1978 National Book Award for Fiction (Going After Cacciato), 1990 Heartland Award and France's Prix du Meilleur Livre Etranger (The Things They Carried), 1991 Melcher Book Award, 1995 James Fenimore Cooper Prize for Historical Fiction (In the Lake of the Woods), 2012 Dayton Literary Peace Prize/Richard C. Holbrooke Distinguished Achievement Award, and 2013 Pritzker Military Library Literature Award.

\section{THE "GOOD” AND THE "BAD” VIETNAM WAR PERIODS}

A study by Hochgesang, Lawyer, and Stevenson at Stanford University reports that in Vietnam, "Psychologists believe that there were two types of war. The first was considered the 'good' war which took place from 1964-1968. The second was the 'bad' war which occurred from 1968-1972" (Hochgesang, Lawyer, and Stevenson, 1999). These authors describe the earlier "good war" of 1964-1968 as the period when the fighting was conventional in a way that the enemies, namely the North Vietnamese Army (NVA) and the National Liberal Front (NLF) in the South (or Việt Cộng [VC], a shortened slang for Vietnamese Communists) could be easily identified and there was direct confrontation between the opposing military forces. The period of "bad war" of 1968-1972 is explained by Hochgesang, Lawyer, and Stevenson as the period when the Vietnam War became a guerrilla war, and the American troops were heavily inflicted by booby traps and mines when they pursued the invisible enemies among civilians who shielded them. As such, the latter situation blurred the difference between the enemy soldiers and civilian noncombatants; therefore, American troops began to view all Vietnamese they encountered as enemies and racially inferior. While this distinction of "good" and "bad" Vietnam War periods has merit in explaining the drastic changes in American troops' morale and action with time, their supporting rationale is flawed and incorrect.

The entire Vietnam War history and timeline have been well documented by historians and scholars (Public Broadcasting Service [PBS], 2018). After enduring more than 100 years under the brutal French colonialism, with the help of communist China, North Vietnamese nationalists led by General Võ Nguyên Giáp and the well-respected communist leader Hồ Chí Minh defeated the French at the decisive battle of Điện Biên Phủ in 1954. The Geneva Accords was signed to divide Vietnam into two regions at the seventeenth parallel to allow France a "face-saving defeat" (PBS, 2018). The Geneva Accords also stipulated that Vietnam would hold elections in 1956 to unite the country. At the same time, it created a 300-day period where people could move freely between the communistcontrolled North and the anti-communist South before the border was sealed on May 18, 1955. Up to a million northern Vietnamese, mostly anti-communist, Catholic, or political refugees (i.e., college-educated professionals, merchants, land owners, etc.) were believed to leave the North and everything they owned to escape potential persecution by the communist regime. During this time the US Navy and the French military helped transport these Northern Vietnamese refugees via ship or aircraft under the Operation Passage to Freedom. Many thousands Northern Vietnamese also risked death to migrate South over land outside the 300-day period, despite being prevented by the communists from leaving. 
To prevent the spread of communism from the North, the Eisenhower Administration supported Ngô Đình Diệm, a Catholic and French-educated politician, to head the Government of the Republic of Vietnam (GVN, or South Vietnam). In 1961, after nearly two decades of indirect military aids, President Kennedy decided to send 3,200 military troops to South Vietnam to act as military advisors to the Army of the Republic of Vietnam (ARVN). This number increased to 16,300 US military advisors in 1963. Inadvertently, the time of easy VC killing came to an end soon after the US got more involved in South Vietnam. John Paul Vann, a well-known US lieutenant colonel advisor and a posthumous Presidential Medal of Freedom recipient, observed as early as 1962 that the advisory mission by President Kennedy unintentionally resulted in equipping the VC with better US ammunitions because VC troops would attack isolated and weakly-held outposts and obtained advanced US arms to be more resilient after US-led attacks (Sheehan, 1988). When Ngô Đình Diệm was overthrown by a coup d'état on November 1, 1963, it was a common belief in military officers working under Diệm that the main reason of the coup d'état was that Diệm did not want the US to send combat ground troops to South Vietnam. President Kennedy was assassinated three weeks later in Dallas, Texas.

In 1964, President Johnson lied to Congress and the American people about the Gulf of Tonkin incident and obtained the Tonkin Golf Resolution from Congress, a blank check to increase US military presence in Vietnam. In his major address at John Hopkins University on April 7, 1965, President Johnson stated, "Why are we in South Viet-Nam? We are there because we have a promise to keep. Since 1954 every American President has offered support to the people of South Viet-Nam. We have helped to build and we have helped to defend. Thus, over many years we have made a national pledge to help South Viet-Nam defend its independence" (The Regents of the University of California [TRUC], 2018). The American public and the entire world at that time did not know that as early as 1965, the US government secretly reported that the Vietnam War was unwinnable, as the situation in South Vietnam was "bad and deteriorating" ("The Pentagon Papers," 1965). The US aim for involvement in South Vietnam then was primarily "to avoid a humiliating US defeat" (70 percent) and to keep South Vietnam and adjacent Indochina territory from Chinese hands (20 percent). The US aim to help South Vietnamese achieve a democratic society and a better life is only 10 percent. Despite this bleak secret report, President Johnson escalated the US involvement in Vietnam by ordering the bombing of North Vietnam (Operation Rolling Thunder) and by increasing the number of American troops sent to Vietnam from 23,000 in 1964 to 184,300 in 1965 and even up to 536,100 in 1968 (TRUC, 2018 p. 29). The role of American troops in Vietnam changed from military advisors to the ARVN to regular combat units; and this significantly increased American troop casualties. Still at the beginning of the Vietnam War, the American public and American troops believed that helping South Vietnam stop the spread of communism was part of their national interest.

From 1960 to 1964, the communist regime in North Vietnam believed that they could win a military victory in the South "in a relatively short period of time" (TRUC, 2018 p. 29). However, as early as December 1965, Hồ Chí Minh and his communist party changed their war tactic in the South to a guerrilla war to counter the American combat troop build-up. The purpose of this type of guerrilla war was to wear out America in a prolonged and undefined war it could not win easily with its outstanding military power. To achieve this objective, VC in South Vietnam stepped up their propaganda, recruitment effort, and the building of enormous underground tunnel systems as their bases. At the same time, more NVA troops, supplies, and ammunitions started to infiltrate the South using the Hồ Chí Minh trail. With their intimate knowledge of the landscape and local people, their focus was to remain invisible and to rely on surprised ambushes, hit and run attacks, mines, booby traps, etc. They did not try to engage in large confrontational battles with American troops unless the odds were in their favor (e.g., be in a close-range battle to avoid reinforced artillery and bombings from the Americans). Thus, during the 1964-1968 period that Hochgesang, Lawyer, and Stevenson (1999) called the "good war" [they meant when the fighting was conventional and confrontational], there were only a few large engagements with VC reported, with a couple of hundred casualties: Âp Bắc (meaning "Northern Hamlet," January 1963), Sông Bé (meaning "Small River," May 1965), Đồng Xoài (meaning "Field of Mangoes,” June 1965), Cồn Tiên (meaning "Hill of Angels," July 1966), and Chu Lai (named after the mandarin name of General Victor Krulak, August 1965). The first few large battles between the American troops and the NVA were at Ia Drang (Ethnic minority name in Central Highlands, September-October 1965) and Đông Hà (meaning "Eastern River," June 1966). During this time, American armed forces and ARVN conducted many large-scale and expensive Search and Destroy Operations: Crimp (8,000 US troops, January 1966); Birmingham (5,000 US troops, April-May 1966); Attleboro (US 196th Brigade, 22,000 ARVN, September 1966); Cedar Falls (16,000 US troops, 14,000 ARVN, January 1967); and Junction City (30,000 US troops, 5,000 ARVN, February1967), etc. However, American troops did not encounter major, head-tohead battles during these conventional war operations. VC and NVA were ever found to be elusive and hard to find (PBS, 2018). By the late 1960s, public support for the Vietnam War in the U.S. was decreasing as the anti-war movement ratcheted up.

From 1968 until the last American combat soldiers left South Vietnam in March 1973, VC and NVA switched their guerilla war tactic to an offensive one to speed up the destruction of the GVN regime, in contrast with the definition of "bad war" by Hochgesang, Lawyer, and Stevenson (1999) [they meant that the fighting was based on the guerilla tactic]. During the Tết Nguyên Đán (Vietnamese New Year Holidays), or Tết offensive late January 1968, scores of VCs and their secret organizers/sympathizers openly attacked more than 100 cities and towns in South Vietnam. It was like the sky had fallen for many democracy-loving South Vietnamese, who found out that many of the people they had trusted their entire life (e.g., local merchants, co-workers, or handymen, etc.) turned out to be VC or VC sympathizers in 
disguise. In addition to killing ARVN officers, soldiers, and their families at occupied military bases, VC and NVA forces also massacred thousands of educated professionals and people working for the Southern government or American bases in the towns they occupied, especially in Huế (meaning "Harmony") (Richburg, 1988). As Americans watched the bloody and deadly fighting of Tết offensive on TV in real time, Vietnam War protests were escalating in the US. Major offensive attacks by VC and NVA on American bases continued in February 1969. At the same time, the on-going, intermittent VC and NVA guerrilla combat tactic in the rest of the country - outside the major offensive areas - remained. After his second inauguration, President Nixon began his "Vietnamization"2 program in the spring of 1969. Nixon started gradual combat troop withdrawal while secretly ordering the bombing and troop attacks of neighboring Cambodia (1970) and Laos (1971). After the Paris Peace Agreement was signed on January 23, 1973, only few Marines protecting some US installations, American military advisors, and American civilians working for the US Embassy in Saigon remained in Vietnam by March 1973. When President Nixon resigned on August 8, 1974, South Vietnam lost its last and strongest advocate. The escalating offense attacks from VC and NVA on the ARVN at the end of 1974 and the financial/military cut from the US caused South Vietnam to finally nail the coffin of its fate. As South Vietnam did not have enough resources (especially ammunition) to defend itself, it collapsed and fell to communism on April 30, 1975.

As discussed above, the distinction of "good" and "bad" Vietnam War periods by Hochgesang, Lawyer, and Stevenson (1999) has merit in explaining the drastic changes in American troops' morale and their consequential action with time, but the "good" war period was not due to the assumed conventional war conducted by opposing military forces in Vietnam. The "good" war period occurred at the beginning of the Vietnam War, when the morale of the American troops was relatively high because both American troops and the American public supported their government decision to stop the spread of communism in Southeast Asia. Only a small amount of volunteered troops were acting as military advisors to work along side the South Vietnamese and ARVN to help improve their life and their skills in battles. By the end of the 1960s decade, when President Johnson required American troops to take on the role of direct combat units, the number of American casualties significantly increased. Moreover, during President Nixon's planned period of combat troop withdrawal, the troops' morale took a dive as American soldiers struggled to stay alive during their one-year service tour ${ }^{3}$, until the day of their DEROS (Date of Expected Return from Overseas). The Army personnel rotation policy that rotated American soldiers through Vietnam on one-year tours and the requirement that officers spent only six months in a troop command position during that one year ${ }^{4}$ had several unintended adverse effects because "prominent military psychiatrists warned that the individual replacement system was having catastrophic consequences on unit cohesion 5 ... and contributed to the Army's declining performance on the battlefield" (DePue, 2006). Therefore, troops and their commanders avoided combat and field operations and instead focused on surviving their tour. By labeling the latter part of the Vietnam War as the "bad" war, it does not mean that there was a lack of courage or honorable deeds in the American armed forces at that time. It only means that the morale, discipline, and action of many soldiers were generally at the lowest point during the Vietnam War.

\section{O’BRIEN’S “BAD” VIETNAM WAR In THE THINGS THEY CARRIED}

O'Brien was sent to Vietnam in 1969, when the US government already started to gradually withdraw combat troops from the country. As stated in his interviews, "By 1969, nobody ever talked about winning... we had been reading enough headlines to absorb the hopelessness of the war" (Ackerman, 2017). Although O'Brien denies that he is a Vietnam War writer, he admits that three of his books "have a lot of Vietnam in them... In the Lake of the Woods occurs after Vietnam and living with the consequences of history and misdeed and horror. Cacciato is a fabulist running-away-from-the war-story. The Things They Carried is a book largely about storytelling and issues about truth" (Hicks, 2005). Unintentionally, O’Brien has addressed, within these three award-winning novels, most of the reportedly important issues about the American troops during the "bad" Vietnam War period - in the most riveting, powerful, and groundbreaking way.

Published 12 years after Going After Cacciato (O'Brien, 1978), O'Brien continues the dialog about American soldiers like himself during the period of the "bad" Vietnam War in The Things They Carried (O'Brien, 1990). Using the format of 22 interconnected short stories, told from the point of view of the soldiers of the Alpha Company (in which the fictional character Tim O'Brien was a member), O'Brien truthfully depicts the anxiety and grief of young soldiers from being drafted and the emotional and psychological tolls of war during their service in Vietnam. Here, O'Brien describes the average age of the American soldiers (19 years old) and touches upon their issues either at the base or in the dangerous booby trap- and mine-laden field: boredom and meaningless death, abusive violence toward Vietnamese noncombatants, drug use, in-fighting, thefts within barracks, grief, rage, self mutilation, mutilation of enemy corpses, and senseless animal or civilian killings. All these descriptions show the human potential for

\footnotetext{
2 "Vietnamization" is a euphemism to mean "let the ARVN do all the fighting themselves," which was practically what Ngô Đình Diệm insisted in the first place.

${ }^{3}$ Unlike in other wars, the one-year service tour in the Vietnam War was designed to provide good morale, help ameliorate the harsh climate and living conditions in Vietnam to troops, and spread the burden of a long war to more draftees. But it created unintended adverse effects.

${ }^{4}$ This is to create a large pool of commanding officers experienced in combat in the event of confrontation with the Soviets during the Cold War.

${ }^{5}$ Combat unit cohesion required leadership experience and a sense of camaraderie not being provided by high turnover rate of new/inexperienced platoon leaders or company commanders.
} 
committing atrocities, while being numbed by surrounding evil acts. Several of the actions and conduct of the soldiers in this novel could be deemed illegal based on the US military Law of War (Department of Army [DoA], 1987; Department of Defense [DoD], 2015). In this mind-captivating book, O'Brien employs many literary devices like imagery, allusion, and repetition to revisit several of his war themes already presented in the 1978 Going After Cacciato, and more.

\section{A. Meaningless Deaths in a Monotonous But Terror-filled Guerilla War}

In The Things They Carried, O'Brien has to recirculate, recollect, repeat, or revisit similar war scenes (some already mentioned in Going After Cacciato) over and over again because those are what form the miserable, inescapable lives of many American combat troops in Vietnam: "There it is, they'd say. Over and over - there it is, my friend, there it is as if the repetition itself were an act of poise, a balance between crazy and almost crazy, knowing without going, there it is, which meant to be cool, let it ride because Oh yeah, man, you can't change what can't be changed, there it is, there is absolutely and positively and fucking well is" (O’Brien, 1990, p. 20). At the beginning of the Vietnam War, O'Brien's American soldiers know that "it was a war to stop the Communists, plain and simple" (O’Brien, 1990, p. 43). But by 1968, O'Brien and most American soldiers hate the war because it seems so wrong (O'Brien, 1990, p. 38). In the safer environment of their barracks, the bored soldiers fight maliciously among each other over trivial things such as barrack theft. Using humor, O'Brien describes one of their in-fighting events, "Lee Strunk and Dave Jensen got into a fistfight. It was about something stupid - a missing jackknife - but even so the fight was vicious" (O’Brien, 1990, p. 59). After breaking Jensen's nose, Strunk is so nervous about potential revenge by Jensen; he is even mortified of being "fragged" by Jensen. Finally Strunk breaks his own nose with a gun to ask Jensen if everything is square between them. Jensen cannot stop laughing because he does indeed steal "his [Strunk's] fucking jackknife." (O'Brien, 1990, p. 61). As for the character Tim O'Brien in the book, he hates to gut the medic Bobby Jorgenson, whose ignorance and inexperience may cause Tim to die of shock after Tim is shot in combat. Elsewhere in the war memoir literature, a frustrated American soldier empties a magazine into the head of his fellow comrade over a simple argument such as refusal to go on guard (Caputo, 2017).

In The Things They Carried, just like in Going After Cacciato, O'Brien's soldiers do not die from heroic actions, they are just, "Greased, they'd say. Offed, lit up, zapped while zipping... they had the lines mostly memorized, irony mixed with tragedy" (O’Brien, 1990, p. 19). Ted Lavender is shot in the head by a sniper; Curt Lemon strips a mine; Kiowa drowns in a village waste field. O'Brien is incorrect here to think that these American soldiers do not die from heroic actions. The fact that they are out in the field patrolling and getting exposed to a multitude of unseen dangers is already heroic; it does not matter if they die not being face-to-face with the enemy or not firing at the enemy. To O'Brien, the deadly Vietnam [guerrilla] War is like, "I remember the monotomy, Digging foxholes. Slapping mosquitoes. The sun and the heat and the endless paddies. Even in the deep bush, where you could die any number of ways, the war was nakedly and aggressively boring. But it was a strange boredom. It was boredom with a twist, the kind of boredom that caused stomach disorders... Well, you'd think, this isn't so bad. And right then you'd hear gunfire behind you and your nuts would fly up into your throat and you'd be squealing pig squeals. That kind of boredom” (O’Brien, 1990, p. 33).

The Vietnam War is so bad that even a kind-hearted, level-headed platoon medic named Rat Kiley eventually succumbs to the stress of war, after his best friend Curt Lemon is blown up into pieces onto a tree by a rigged $105 \mathrm{~mm}$ artillery shell. After mercilessly torturing and killing a baby buffalo with his rifle and seeing many more body bags, Rat Kiley finally mutilates himself to get out of war, “'This whole war,' he said. 'You know what it is? Just one big banquet. Meat, man. You and me. Everybody. Meat for the bugs.' The next morning he shot himself. He took off his boots and socks, laid out his medical kit, doped himself up, and put a round through his foot" (O'Brien, 1990, p. 212). This event shows that to avoid dangerous combat or field patrol assignment - and potential unseen serious injury and death associated with it - many American soldiers are not afraid of intentionally injuring and disabling themselves. During the 1968 Mỹ Lai Massacre, the only American casualty was the case of one American soldier [PFC Carter] who shot himself in the foot, so that he would not have to participate in the killing of noncombatant Vietnamese villagers.

\section{B. "Abusive Violence" toward Vietnamese Noncombatants}

During their combat operation in the field, the familiar scene of destroying the entire village ${ }^{6}$ is repeated in The Things They Carried, "After the chopper took Lavender away, Lieutenant Jimmy Cross led his men into the village of Thận Khê. They burned everything. They shot chicken and dogs, they trashed the village well, they called in artillery and watched the wreckage..." (O'Brien, 1990, p. 15). The civilian deaths and the painful agony of the few who survive the napalm or phosphorous bombings are depicted in the chapter about a girl dancing in the middle of the attack on her village. Perhaps war trauma had made her lose her mind, "There was no music. Most of the hamlet had burned down, including her house, which was now smoke, and the girl danced with her eyes half closed, her feet bare... Later we found her family in her house. They were dead and badly burned... When we dragged them out, the girl kept dancing" (O'Brien, 1990, p. 129). Nothing more needs to be said; these sad and "bad" war stories would go on and on.

But O'Brien as an author neglects to mention somewhere, either in his numerous author interviews or in his novels' footnotes, that many of the actions of the American troops depicted in his novels are illegal and can be prosecuted

\footnotetext{
${ }^{6}$ This typical scene of destroying and wasting the entire village is described in Going After Cacciato.
} 
according to the US Law of War. The 1984 (short version) Field Manual 27-2 entitled "Your Conduct in Combat Under the Law of War" published by the US Department of Army (DoA) (no effort was spent to locate an earlier version during the Vietnam War) clearly specifies how combat troops should treat noncombatant civilians. Page 5 of the FM-27 states, "Don't attack noncombatants... Humane treatment of noncombatants may produce valuable information, gain active support for you, and deny support for the enemy. Mistreatment serves only the interests of the enemy" (DoA, 1984). Page 8 specifies that soldiers should not, "cause destruction beyond the requirement of your mission - Under the laws of war, you are not allowed to attack villages, towns, or cities... Don't destroy an entire town or village to stop sniper fire from a single building. Use only that firepower necessary to neutralize the sniper. Limit destruction only to that necessary to accomplish your mission. Avoid unnecessary loss of life and damage to property. This law not only conserves your own supplies, but preserves facilities for future civilian use" (DoA, 1984). Page 15 emphasizes, "For instance, you might be extremely angry and upset because your unit has taken a lot of casualties from enemy booby traps or hit-and-run tactics. But you must never engage in reprisals or acts of revenge against any persons, enemy or civilian, whom you capture or detain in combat" (DoA, 1984). And the rest of the FM 27-2 explains, "Do not strengthen the enemy's will to fight by needlessly ravaging private property and terrorizing civilians... It may be difficult to understand the rage and anguish of seeing personal property destroyed and personal rights abused. In this century, the American soldier has always fought on foreign soil. Therefore, our land and people have not been torn and devastated by the destruction of war. Unnecessary destruction of property and inhumane treatment of civilians are violations of the law of war for which you can be prosecuted... [emphasis added] (DoA, 1984, p. 20) Make sure civilians are protected from acts of violence, threats, and insults... (DoA, 1984, p. 21). Also, the Geneva Conventions forbid retaliating against civilians for the actions of enemy soldiers (DoA, 1984).

As seen above, O'Brien's soldiers in The Things They Carried were doing all the opposite of their military laws specified in the US Law of War. It is noted that to uphold the law and order of war, Lieutenant Colonel John Paul Vann ${ }^{7}$ opposed the indiscriminate bombardment of villages and killing of noncombatants since 1961, because some rural areas could have been under the VC control and the villagers could not defy the VC rules (Sheehan, 1988). In South Vietnam, it was known that village or hamlet chiefs and educated, professional people were often assassinated by VC (Stur, 2017). Even Vietnamese children who were friendly to American forces were reported to be killed by VC and NVA (Laufer et al., 1984). Similar to General Douglas McArthur's war philosophy, Lieutenant Colonel John Paul Vann and his immediate supervisor, Colonel Daniel Boone Porter, thought of the soldiers as "champions of the weak" because they had seen so many old villagers and children being killed by artillery or bombardment. Just like what is stated in FM-27, Vann believed that harming the poor peasants would drive "these people right into the arms of the Viet Cong" (Sheehan, 1988, p. 113). Vann was powerless to recognize that the air service, artillery, and every branch of the armed forces wanted "as big a role as possible" in the Vietnam War as early as 1961 - when President Kennedy committed the United States to the war; so the indiscriminate bombing/shelling and killing of innocent civilians continued throughout the duration of the Vietnam War.

In a study on the Vietnam Veteran's war stress and trauma, researchers from Brooklyn College and Columbia University found that American soldiers who showed alienation and racial hostility toward the Vietnamese had acquired the ability to destroy villages and kill civilians at ease, "I started to lose my respect for life... you could be eating dinner and get up and walk out and wipe out $60 \ldots 80 \ldots 90$ people and go right back and sit down and eat," because "To me, they were all the same... South Vietnamese or Viet Cong, they were all the same... I mean killing a gook was nothing really. It didn't bother me at all. I could have butchered them like nothing really..." (Laufer et al., 1984). These soldiers not only hated Vietnamese, they despised and looked down on the very people their government claimed to come to protect, “...I was very negative about the Vietnamese. I hated them... They were the sorriest race of people I ever run upon my life... The moral decay, the degeneracy of the little kids... I had a dislike for most of them... they were so far removed from any civilization..." (Laufer et al., 1984). As such, these American soldiers often cited "rage, fear, and/or anxiety... seeking some means of controlling their environment" (Laufer et al., 1984) to be the reasons for their abusive violence. But Lieutenant Colonel John Paul Vann thought differently, as Sheehan wrote, "John Vann had come to Vietnam to wage war on other men [VC, NVA], not on their mothers and fathers or on their wives and children. That these people were relatives of guerrillas, and undoubtedly did sympathize with the Viet Cong and helped them, did not strip them of their noncombatant status... Rather, they were people whom the Saigon Government ought to be seeking to win over by fair treatment so that they would talk their sons and husbands into deserting the Communist ranks" (Sheehan, 1988, p. 109). Being at war does not mean to be savage and lawless. As the most powerful and the most civilized democratic country in the world, the US needs to be exemplary both in war and in peace.

\section{Drug Epidemic}

In his 1971 paper entitled "The Collapse of the Armed Forces," Colonel Robert D. Heinl, Jr. reports that like their parent society during the 1960s and early 1970s, American armed forces were struggling with the drug epidemic in an unprecedented proportion (Heinl, 1971). The first soldier who died in The Things They Carried is a sweet young fellow,

\footnotetext{
${ }^{7}$ John Paul Vann was killed in 1972 in a helicopter accident and was awarded the Presidential Medal of Freedom, the second highest nation's honor.

${ }^{8}$ Based on General Douglas McArthur's quote: "The soldier, be he friend or foe, is charged with the protection of the weak and the unarmed, it is his very existence for being."
} 
Ted Lavender, who needs drugs to calm him down, "Until he was shot, Ted Lavender carried 6 to 7 ounces of premium dope, which for him was a necessity” (O’Brien, 1990, p. 3). O’Brien does not mention how many of the soldiers in the Alpha Company use drugs, but it appears that it is not a minority, "After wrapping him in his poncho, they sat and smoke Ted's dope until the chopper came (O'Brien, 1990, p. 6, 19). According to Heinl, drug use in the military poses a whole "NEW" problem for the US armed forces during the Vietnam War. A Congressional committee found in April 1971 that about 12 to 15 percent of American troops in Vietnam were using high-grade heroin. In 1966, the Navy discharged a total of 170 drug offenders; by 1970 , that number jumped to over 5,000. In addition to poor troop performance, Heinl states that the drug addiction problem causes many undesirable side effects to the US armed forces such as barrack theft and criminal offenses inside military and naval bases that once "had the safest streets in America." After coming back from the war, these drug-addicted war veterans also have bigger problems of staying productive and integrating back to society. In many cases, they are denied employment because of the drug use stigma.

\section{Senseless Mutilation of Animals and Enemy/Civilian Bodies and Corpses}

In The Things They Carried, O'Brien for the first time describes the act of mutilation of live animals and human corpses as a common action by the American armed forces, when the average age in their platoon is nineteen or twenty. In the very first chapter, O'Brien writes, "Norman Bowker, otherwise a very gentle person, carried a thumb that had been presented to him as a gift by Mitchel Sanders. The thumb was dark brown, rubbery to the touch, and weighed 3 ounces at most. It had been cut from a VC corpse, a boy of fifteen or sixteen" (O'Brien, 1990, p. 12); "They kicked corpses. They cut off thumbs" (O'Brien, 1990, p. 19). In a subsequent chapter entitled "Sweetheart of the Sông Trà Bồng” (meaning "River of Carrying Tea"), O’Brien mentions a possibly true story (Coffey, 1990) about an American girl that he names Mary Anne Bell, a high school cheerleader from Ohio, who goes to the war zone to visit her boyfriend to-be-married Mark Fossie. There, she is totally pulled into the excitement of nightly raids with the Green Berets stationing next door that she leaves her lover to pursue danger-seeking thrills. O'Brien explains that the next time she is seen by Mark, "At the girl's throat was a necklace of human tongues. Elongated and narrow, like pieces of blackened leather, the tongues were threaded along a length of copper wire" (O'Brien, 1990, p. 106). The hootch she shared with the Special Armed Force soldiers was filled with some powerful stench of blood, excrement, decaying flesh, etc., "And bones. Stacks of bones - all kinds. To one side, propped up against a wall, stood a poster in neat black lettering: ASSEMBLE YOUR OWN GOOK!! FREE SAMPLE KIT!!” (O’Brien, 1990, p. 105). The senseless act of mutilating the corpses of the enemy that O'Brien describes in The Things They Carried has also been confirmed in recent Vietnam War literature (Kifner, 2003). For four days from October 19 to October 22, 2003, The Blade, a daily newspaper serving Toledo, Ohio published the [2004 Pulitzer-winning] results of their eight-month investigation, which documented the killing spree of numerous unarmed civilians, including rape and torture, and the practice of cutting off the ears and scalps of the Vietnamese corpses for souvenirs by the Tiger Force paratroops (Harris, 2003; Sallah, 2017; Sallah and Weiss, 2006).

The act of mutilating enemy corpses is a violation of both the Geneva Conventions and US military Law of War. The 1949 Geneva Convention IV, Article 16, second paragraph states, "As far as military considerations allow, each Party to the conflict shall facilitate the steps taken... to protect [the killed] against... ill treatment" (International Committee of the Red Cross [ICRC], 2018). On page 430 of the comprehensive 1204-page "Department of Defense Law of War Manual" published in 2015, Section 7.7.1.1 (No Disrespectful or Degrading Treatment of the Dead) specifies, "Enemy military dead must be protected from disrespectful or degrading acts. For example mutilation or cannibalism of dead bodies is prohibited" (DoD, 2015). Footnote No. 132 on Page 431 of this Law of War Manual addresses the past Vietnam War situation as follows, "Reports of the mutilation of bodies, particularly cutting the ears off dead enemy soldiers, also circulated. One of such incident was filmed and shown on the CBS Evening News in 1967... The disciplinary or judicial action taken in these incidents is proof that such conduct was not sanctioned by the command in Vietnam. In October 1967, General Westmoreland, United States Commander in Vietnam, described the practice of cutting ears and fingers off the dead as 'subhuman' and 'contrary to all policy and below the minimum standards of human decency" (DoD, 2015). Furthermore, the subhuman act of mutilating the dead corpses has serious religious violations. It is because virtually all religions, including Christianity, have "reverence" for the dead. Because of the belief of resurrection, respect for the dead has been a core teaching within Catholicism and Christianity (Sacirbey, 2012). It is ironic that some American soldiers embraced the "mere gook rule" that considered Vietnamese people to be "subhuman" to make it easier for them to kill, whereas those soldiers who practiced the act of mutilating dead Vietnamese corpses were in turn called by General Westmoreland, the commander of the US Military Assistance Command in Vietnam (MACV) as engaging in "subhuman" act.

Another disturbing issue raised by O'Brien in The Things They Carried is the senseless mutilation of live animals by American troops. One incidence is based on O'Brien's actual witnessed account of the savage killing of a water buffalo (Gross, 2010). After Curt Lemon, Rat Kiley' best friend is killed by a rigged $105 \mathrm{~mm}$ artillery shell, Kiley takes his rage and pain out on a poor baby water buffalo, "He stepped back and shot it through the right front knee... It went down hard, then got up again, and Rat took careful aim and shot off an ear. He shot it in the hindquarters and in the little hump at its back. He shot it twice in the flanks. It wasn't to kill; it was to hurt. He put the rifle muzzle up against the mouth and shot the mouth away. Nobody said much... He shot off the tail. He shot away chinks of meat below the ribs... Rat went automatic... Rat shot it in the nose... then he shot it in the throat... Somebody kicked the baby buffalo. 
It was still alive, though just barely, just in the eyes... Kiowa and Mitchel Sanders picked up the baby buffalo... and dumped it in the village well... Mitchell Sanders took off his yo-yo. 'Well, that's Nam,' he said. 'Garden of Evil. Over here, man, every sin's real fresh and original'" (O'Brien, 1990, p. 75-76). So vivid, so lucid are these details, to show the cruel act and the complicit behavior of the American troops when they witness atrocities committed by their fellow soldiers. Another story related to the case of Azar using a Claymore antipersonnel mine to blow up an orphan baby puppy that Ted Lavender adopts and lovingly "feeding it from a plastic spoon and carrying it in his rucksack." In response to his platoon's opinion about his cruel action, Azar defends himself, "'What's everybody so upset about?' Azar said. 'I mean, Christ, I'm just a boy"' (O'Brien, 1990, p. 35). If a prank or horseplay from young boys is to blow up an innocent puppy with an explosive device, we would have a serious moral problem in our society. Perhaps O'Brien does not think that the true story of cruel mutilation of a baby water buffalo is about the evil of war, it is about the strong bond and buddy love between Curt Lemon and Rat Kiley. Still, when one is capable of senselessly mutilating and inflicting pain on an innocent animal, the next step of mutilating and killing human beings is not too far off, as justice professionals explain, "The Link between violence to people and violence to animals is well documented by research, both nationally and internationally" (Phillips, 2014).

\section{E. Rare Collaboration with Civilians}

Page 5 of the 1984 DoA Field Manual 27-2 states an observation that is proved to be correct in The Things They Carried, "Humane treatment of noncombatants may produce valuable information, gain active support for you, and deny support for the enemy" (DoA, 1984). In the chapter entitled Spin, O'Brien describes a touching collaboration effort between the American troops and a poor villager, "And like the time we enlisted an old poppa-san to guide us through the mine fields out of Batangan Peninsula. The old guy walked with a limp, slow and stooped over, but he knew where the safe spots were... Rat Kiley made up a rhyme that caught on... Step out of line, hit a mine; follow the dink, you're in the pink... in those five days on the Batangan Peninsula nobody got hurt. We all learned to love the old man... Jimmy Cross gave the old papa-san a hug. Mitchell Sanders and Lee Strunk loaded him up with boxes of C rations. There were actually tears in the old guy's eyes. 'Follow dink,' he said to each of us, 'you go pink'" (O'Brien, 1990, p. 32). This old villager does not know the contemptuous meaning of "Dink" that the American troops call him, when he is helping them. He risks his own life to save the entire platoon, just because these young foreign soldiers are kind to him. A few boxes of $\mathrm{C}$ rations will not sustain him long enough. If the local VC or NVA catch him helping the Americans, he (and perhaps his entire family) can be tortured and executed (Laufer et al., 1984).

\section{F. Guilt and Looking at the Bright Side}

In The Things They Carried, the author O'Brien does not mention the remorse in the American troops when they committ atrocities in poor Vietnamese villages, except some subtle guilt that the character O'Brien in the book experiences after he throws a grenade that kills a young VC soldier, "His jaw was in his throat, his upper lip and teeth were gone, his one eye was shut, his other eye was a star-shaped hole" (O'Brien, 1990, p. 119). In fact, there is actually a picture of a dead Vietnamese man with a similar description "his jaw was in this throat" because he was shot into the face. He was an unarmed civilian killed by the Charlie Company soldiers during the Mỹ Lai Massacre (Lawrence, 2018). Unlike many American troops who killed unarmed civilians without remorse, the character O'Brien in the book recalls that he does not even hate the VC, "It was entirely automatic... I did not hate the young man; I did not see him as the enemy (O'Brien, 1990, p. 126)... It occurred to me that he was about to die. I wanted to warn him (O'Brien, 1990, p. 127)... For me, it was not a matter of live or die. I was in no real peril. Almost certainly the young man would have passed me by. Sometimes I forgive myself, other times I don't' (O'Brien, 1990, p. 128). Seeing that the young man he kills has clean finger nails and also wears a gold ring, the character O'Brien imagines that the young VC must be a math university student who is forced to join the VC at his home village (O'Brien, 1990, p. 122) and has been a soldier for just a sjngle day (O’Brien, 1990, p. 123). This act of imagination puts a human touch to the victim and neutralizes the conflict in war.

More often in The Things They Carried, O'Brien describes the guilt in American troops when their fellow soldiers are killed. When the first platoon member Ted Lavender dies because of a sniper's attack, their leader Lieutenant Jimmy Cross puts the blame on himself for being distracted by his love interest for Martha, a young woman who does not return Jimmy's love and becomes a nun later. So, "On the morning after Ted Lavender died, First Lieutenant Jimmy Cross crouched at the bottom of his foxhole and burned Martha's letters. Then he burned the two photographs... Lavender was dead. You couldn't bury the blame" (O'Brien, 1990, p. 22). This sense of responsibility isn't just present at the commanding level. It is repeated when Norman Bowker cannot handle the horrid human slime and lets his friend Kiowa drown in the village waste field. At Norman's request, O'Brien writes, "Sometimes, like that night in the shit field, the difference between courage and cowardice was something small and stupid... when he got there Kiowa was almost completely under (O'Brien, 1990, p. 142)... The shit was in his nose and eyes. There were flares and mortar rounds, and the stink was everywhere-it was inside him, in his lungs-and he could no longer tolerate it... Not here, he thought. Not like this. He released Kiowa's boot and watched it slide away" (O'Brien, 1990, p. 143). Because he cannot save his friend, Norman lives with an immense guilt when he comes back from the war. He writes to O'Brien to ask the latter to write about Kiowa on his behalf and then committs suicide later in a gym (O'Brien, 1990, p. 149). 
Deep friendship in the military also causes one to glorify his friend's sudden death to ameliorate the pain. Even in the most distressing moment when Curt Lemon is blasted by a mine, O'Brien uses the allusion of an angel going to heaven to describe that fateful moment, "They were just goofing. There was a noise, I suppose, which must've been the detonator, so I glanced behind me and watched Lemon step from the shade into bright sunlight... A handsome kid, really... and when he died it was almost beautiful, the way the sunlight came around him and lifted him and sucked him high into a tree full of moss and vines and white blossoms" (O'Brien, 1990, p. 67). In fact, Lemon is blown up into pieces, so that the character O'Brien and his fellow soldiers have to climb up the tree later to recover parts of Lemon's body.

\section{CONCLUSIONS}

Like it or not, O'Brien is a Vietnam War novelist because he adroitly paints the complete war picture in his military life and the life of other American soldiers during this somber part of the US history. By blending his Vietnam War experience with known facts about the life and morale of other American soldiers, perhaps O'Brien wants to re-appeal the national conscience about atrocities committed by American troops during the Vietnam War. In his novels, O'Brien uses diverse settings, vivid imaginary, and repetition to illustrate the American perspectives during this immoral and unpopular war. The issues raised by O'Brien in The Things They Carried include meaningless death of troops, abusive violence toward Vietnamese noncombatants, drug epidemic, senseless mutilation of animals and enemy/civilian bodies and corpses, etc. As some of these acts depict troop violation of the US Law of War and show low troop morale, they prove why the US, the biggest firepower in the world, was handily beaten by an impoverished and tiny third world nation. But to paint the entire Vietnam War picture the way O'Brien describes in The Things They Carried and to believe that all those 58,000 American soldier deaths are meaningless is a deep betrayal to those who sacrificed and to the conscientious American parents who spent a great part of their adult life to instill values in their children. To heal and to grow as a nation, we need a searchable database of personal stories of those soldiers who courageously helped South Vietnam and other countries in the world fight for their democracy and freedom - like Hugh Thompson, discussed in “Tim O'Brien's 'Bad' Vietnam War: In the Lake of the Woods and Its Historical Perspective" (Mahini et al., 2018, in press). And we need to start this effort NOW before all the Vietnam vet generation start losing their memory or leave this world behind. Perhaps when teaching O'Brien's war writing, all American teachers and professors need to assign another side project to their smart and curious students: Do some serious research to add more stories of true Vietnam War heroes or heroic stories to the national database, while being aware of military imposters and falsified medal citations, starting with: www.amervets.com; thewall-usa.com; www.vvmf.org/Wall-of-Faces; or www.homeofheroes.com/moh/states/1_states.html for databases of war heroes.

\section{REFERENCES}

[1] Ackerman, E. (2017). Tim O'Brien on What We All Can Learn from Ken Burns' 'The Vietnam War.' The Daily Beast.com, September 24. https://www.thedailybeast.com/tim-obrien-on-what-we-all-can-learn-from-ken-burns-the-vietnam-war (accessed 30/3/2018).

[2] Buchholz, B. (2012). The First Word: Tim O'Brien on life, literature, and peace. Home \& Leisure, November 10. https://www.austin360.com/lifestyles/the-first-word-tim-brien-life-literature-and-peace/3elcGePEV7s4nDxim2sEVK/ (accessed 30/3/2018).

[3] Caputo, P. (2017). A Rumor of War. The Classic Vietnam Memoir. 40th Anniversary Edition. Picador, New York.

[4] Coffey, M. (1990). Tim O'Brien: inventing a new form helps the author talk about war, memory and storytelling (PW Interviews). Publishers Weekly, 16 February.

[5] Department of the Army (DoA). (1987). Your Conduct in Combat Under the Law of War. November 23, 1984. Field Manual (FM) 27-2. https://www.loc.gov/rr/frd/Military_Law/pdf/conduct-in-combat-1984.pdf (accessed 30/3/2018).

[6] Department of Defense (DoD). (2015). Department of Defense Law of War Manual. Office of General Counsel. June. https://www.defense.gov/Portals/1/Documents/law_war_manual15.pdf (accessed 30/3/2018).

[7] DePue, M. (2006). Vietnam War: The Individual Rotation Policy. Originally published in the December 2006 Issue of Vietnam Magazine. http://www.historynet.com/vietnam-war-the-individual-rotation-policy.htm (accessed 8/06/2018).

[8] Ellingwood, S. (2017). Readers Weighed in on the Best Books About the Vietnam War. The New York Times. September 15. https://www.nytimes.com/2017/09/15/books/20-must-read-books-on-the-vietnam-war.html (accessed 1/4/2018).

[9] Gross, T. (2010). Author Interviews "Things They Carried Back" from Vietnam. May 31. https://www.npr.org/templates/transcript/transcript.php?storyId=127133594 (accessed 31/3/2018).

[10] Harris, P. (2013). Vietnam killing spree revelations shock US. The Guardian, October 26. https://www.theguardian.com/media/2003/oct/26/pressandpublishing.usnews (accessed 30/3/2018).

[11] Heberle, M. A. (2001). A Trauma Artist - Tim O'Brien and the Fiction of VIETNAM. University of Iowa Press. Iowa City.

[12] Heinl, Jr., Col. Robert D. (1971), "The Collapse of the Armed Forces." Armed Forces Journal, 7 June. https://msuweb.montclair.edu/ furrg/Vietnam/heinl.html (accessed 30/3/2018).

[13] Hicks, P. (2005). A Conversation with Tim O’Brien. Indiana Review: 27 (2), pp. 85-95.

[14] Hochgesang, J., T. Lawyer, and T. Stevenson. (1999). The Psychological Effects of the Vietnam War. Ethics of Development in a Global Environment (EDGE). https://web.stanford.edu/class/e297c/war_peace/media/hpsych.html (accessed 21/3/2018).

[15] International Committee of the Red Cross (ICRC). (2018). Practice Relating to Rule 113. Treatment of the Dead. Section A. Respect for the Dead. https://ihl-databases.icrc.org/customary-ihl/eng/docs/v2_rul_rule113 (accessed 22/4/2018). 
[16] Kent, A. (2015). The Most Expensive Wars in U.S. History. May 21. https://247wallst.com/special-report/2015/05/21/themost-expensive-wars-in-u-s-history/ (accessed 4/4/2018).

[17] Kifner, J. (2003). Report of Brutal Vietnam Campaign Stirs Memories. The New York Times, December 28. https://www.nytimes.com/2003/12/28/us/report-on-brutal-vietnam-campaign-stirs-memories.html (accessed 4/4/2018).

[18] Laufer, R. S., M.S. Gallops, and E. Frey-Wouters. (1984). War Stress and Trauma: The Vietnam Veteran Experience. Journal of Health and Social Behavior: 25 (1), pp. 65-85.

[19] Lawrence, Q. (2018). 50 Years On, My Lai Massacre Remains A Gaping Wound. National Public Radio (NPR). March 16. https://www.npr.org/2018/03/16/594364462/my-lai-massacre-of-1968-continues-to-resonate-in-america (accessed 4/4/2018).

[20] Mahini, R. N-T., E. Barth, and J. Morrow. (2018). Tim O'Brien's 'Bad' Vietnam War: In the Lake of the Woods and Its Historical Perspective. Theory and Practice in Language Studies, Volume 8, Issue 12, December (in press).

[21] O’Brien, T. (1978). Going After Cacciato. Broadway Book, Random House, Inc. New York.

[22] O'Brien, T. (1990). The Things They Carried. Houghton Mifflin Harcourt Publishing Company. New York.

[23] O'Brien, T. (1994). The Vietnam in Me. The New York Times, 2 October. https://archive.nytimes.com/www.nytimes.com/books/98/09/20/specials/obrien-vietnam.html (accessed 30/3/2018).

[24] Phillips, A. (2014). Understanding the Link between Violence to Animals and People. A Guidebook for Criminal Justice Professionals. National District Attorneys Association. http://nationallinkcoalition.org/wp-content/uploads/2014/06/AlliesLink-Monograph-2014.pdf (accessed 30/3/2018).

[25] Public Broadcasting Service (PBS). (2018). A Brief History. Battlefield Vietnam. http://www.pbs.org/battlefieldvietnam/history/index.html (accessed 1/4/2018).

[26] Richburg, K. B. (1988). 20 Years After Hue, Vietnamese Admit 'Mistakes.' Washington Post, February 3. https://www.washingtonpost.com/archive/politics/1988/02/03/20-years-after-hue-vietnamese-admit-mistakes/263c2b5b-294246d7-8d17-17fe35682f83/?utm_term=.9f00745e66ac (accessed 4/4/2018).

[27] Sallah, M. (2017). The Tiger Force Atrocities. Opinion, The New York Times, September 26. https://www.nytimes.com/2017/09/26/opinion/vietnam-tiger-force-atrocities.html (accessed 4/4/2018).

[28] Sallah, M. and M. Weiss, (2006). Tiger Force: A True Story of Men and War. Tie Warren Book Group, New York.

[29] Sacirbey, O. (2012). Desecration of the dead defies religious teachings. January 24. Web. Accessed April $1,2018$. https://www.christiancentury.org/article/2012-01/bodily-desecration-disturbing-why (accessed 4/4/2018).

[30] Sheehan, N. (1988). A Bright Shining Lie. John Paul Vann and America in Vietnam. Random House, Inc., New York.

[31] Stur, H. (2017). The Viet Cong Committed Atrocities, Too. Opinion. The New York Times. December 19. https://www.nytimes.com/2017/12/19/opinion/vietcong-generals-atrocities.html (accessed 8/06/2018).

[32] The Regents of the University of California (TRUC). (2018). Cold War American Lesson \#4: The Vietnam War, 2013, pp. 2223. http://chssp.ucdavis.edu/cwa4-vietnam.pdf/view (accessed 30/3/2018).

[33] The Pentagon Papers. (1965). Gravel Edition, Volume 3, pp. 694-702. Draft Memorandum from McNaughton to Robert McNamara, "Proposed Course of Action re: Vietnam" (draft), 24 March. https://www.mtholyoke.edu/acad/intrel/pentagon3/doc253.htm (accessed 30/3/2018).

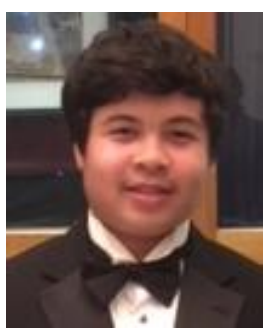

Noor (meaning Light) Mahini (full name Ramtin Noor-Tehrani Mahini) was born in October 2001 in Berkeley, CA and is currently a senior at Acalanes High School in Lafayette, CA, USA. This article was written during his junior year. Noor has been a high-achieving student since middle school, excelling in computers, math, and science. He applies deep critical thinking in most things he does, either in designing computer science projects or in writing English essays. Raised by first-generation immigrant parents (Ramtin $\mathrm{T}$. and Xuannga, who received $\mathrm{PhD} /$ engineering and $\mathrm{MPH} /$ toxicology, respectively, from University of California, Berkeley), Noor's life purpose is to develop a morally respectable character and to become a responsible, devoted citizen to his people/his country and an advocate for human rights.

Noor is a third-degree black belt in Tae Kwon Do and enjoys swimming, tennis, and golf. He is currently doing long-term volunteer work at Youth Tennis Advantage (YTA) to assist children with academics and tennis. Although he loves piano, he is better in viola as he has been playing viola in school orchestras for 5+ years. Regardless of what his career aspiration may be, his life goal is to keep designing useful products and help make this world a better place for all.

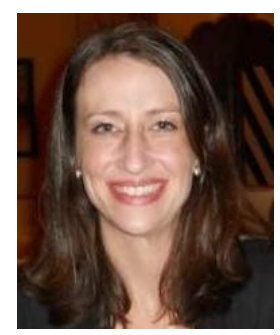

Erin Barth received her Bachelor's and Master's degrees as well as her teaching credential from University of California, Davis, USA.

She is currently an English teacher at Acalanes High School in Lafayette, CA. She lives with her husband Ben, daughter Madeline, and their two Boxers Fletcher and Calvin.

Mrs. Barth enjoys going the extra mile for her students. She is always willing to spend time after school in order to help her students improve their writing skills and develop their appreciation for literature. 


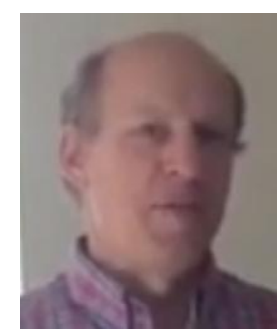

Jed Morrow, being a son of an American WWII veteran, has natural curiosity, special interest, and in-depth knowledge about wars. He lives with his family in the San Francisco Bay Area.

He is currently an AP US History teacher at Acalanes High School in Lafayette, CA. He always challenges his students' critical thinking capability by enthusiastically sharing rare primary source documents with them.

In addition to academic teaching, Mr. Morrow stays physically active by being a great sport coach admired by his students, especially track and field and cross country. 